\title{
Adoption Status of Various Sowing Practices of Protected Cultivation of Vegetables in Punjab, India
}

\author{
Kamalpreet Kaur $^{1 *}$, Prabhjot Kaur ${ }^{1}$ and Kulbir Singh ${ }^{2}$ \\ ${ }^{1}$ Department of Extension Education, ${ }^{2}$ Department of Vegetable Sciences, \\ Punjab Agricultural University, Ludhiana 141004 Punjab, India \\ *Corresponding author
}

\begin{tabular}{|c|}
\hline Keywords \\
\hline $\begin{array}{l}\text { Protected } \\
\text { cultivation, } \\
\text { Adoption, } \\
\text { Micronutrient, } \\
\text { Organic } \\
\text { formulation, } \\
\text { Sowing practices. }\end{array}$ \\
\hline Article Info \\
\hline $\begin{array}{l}\text { Accepted: } \\
07 \text { October } 2017 \\
\text { Available Online: } \\
10 \text { December } 2017\end{array}$ \\
\hline
\end{tabular}

\section{Introduction}

Vegetables are rich source of protein, carbohydrates, minerals and fibre (Weinberger and Lumpkin, 2007). India is the second largest producer of vegetables in the world, next to China. Area under vegetable cultivation in India is 9465.30 thousand hectare with production of 168502.90

The study was conducted to know the adoption status of various recommended sowing practices in protected cultivation of vegetables in six districts of Punjab viz., Amritsar, Gurdaspur, Sangrur, Moga, Jalandhar and Kapurthala. A total of 150 respondents were selected for the study by probability proportion of number of farmers practicing protected vegetable cultivation from the selected districts and the data were collected by personally interviewing the respondents. The results revealed that maximum number of respondents $(64.37 \%)$ grown capsicum in protected structures followed by 58.62 per cent for cucumber and 21.84 per cent for tomato crop in the protected structures. Majority of growers preferred poly house for cultivation of these crops followed by net house. Neem cake, trichoderma and vermicompost were mostly used by respondents under protected structures. Study also revealed that majority of the respondents adopted soil testing practices to get the actual micronutrient status of soil, shallow soil ploughing and applied organic formulation before sowing of crops under protected structures. Majority of tomato growers followed soil solarisation practices under protected structure to reduce the soil born infections. Majority of capsicum and tomato grower prepare their own nursery and used pretreated seed under protected structures. Majority of capsicum and tomato growers did not adopt recommended seed rate and sowing time practices. Majority of tomato growers did not adopt recommended spacing practices while adopt recommended transplanting time practices while in capsicum, maximum number of growers adopt recommended spacing practices and did not adopt recommended transplanting time practices. In case of cucumber, majority of respondents did not adopt recommended seed rate, spacing practices, used pretreated seed and adopt recommended sowing time practices. Therefore regular awareness camps and training courses should be organised to train the farmers for successful cultivation of vegetable crops under protected structures and adoption of these technologies at large scale. 
increasing population, there is a need to enhance the productivity and production potential of vegetables through modified strategies like protected cultivation of vegetables. Olericulturist and extension specialists will have to do some efforts together to achieve the desired level of production potential (George and Singh, 2006). Protected cultivation is one of the best technologies to enhance the production, quality and productivity of vegetable crops. Protected cultivation technology is a technique in which plant microclimate is partially or fully controlled artificially as per the requirement of specific crops to improve the yield potential of crop and to alleviate one or more abiotic stress for optimum growth of crop plants (Satyasai and Viswanathan, 1996). In the $21^{\text {st }}$ century, for off season production of vegetables, to avoid glut in main season and for superior quality of vegetables with high production, protected cultivation is the best choice for efficient utilization of natural resources (Chandra et al., 2000). This study enlightened the vegetable crops grown under protected structures and adoption status of various sowing practices of different vegetable crops grown under protected structures.

\section{Materials and Methods}

The study was conducted in six districts of Punjab viz., Amritsar, Gurdaspur, Sangrur, Moga, Jalandhar and Kapurthala. A list of total vegetable growers in selected districts was prepared with the help of Department of Horticulture, Punjab. From this list, 150 farmers who had adopted protected vegetable cultivation were selected according to probability proportion of number of farmers practicing protected vegetable cultivation in the selected districts. From these 150 respondents, 87 respondents who are continuing with protected vegetable cultivation were contacted for the purpose of present study. An interview schedule was designed for data collection. The schedule dealt with the statements to know the crop grown, type of protected structures, preparation of field, formulations used for successful crop under protected vegetable cultivation and sowing practices of different vegetables under protected conditions. The data were collected through personally interviewing the respondents and analyzed with the help of statistical tools such as frequency and percentage methods.

\section{Results and Discussion}

\section{Crops grown under different protected structures}

Vegetables crops like capsicum, tomato and cucumber were popular for the protected cultivation technologies. Maximum number of respondents $(64.37 \%)$ had grown the capsicum crop in protected structures followed by 58.62 per cent of respondents grown cucumber while 21.84 per cent of respondents were cultivating tomato in the protected structures (Table 1). About 16 per cent of respondents grew both capsicum and cucumber whereas about nine per cent of them cultivating capsicum along with tomato in protected structures (Table 1). About seven per cent of respondents were cultivating all these crops (tomato, cucumber and capsicum) in the protected structures while about six per cent of them were growing tomato along with cucumber crops (Table 1). Neem cake, trichoderma and vermicompost were mostly used by respondents under protected structures in capsicum, tomato and cucumber crop. It was concluded from the discussion that capsicum crop was more preferred by respondents for growing under protected structures. Similar results were reported by Kumar (2008) that majority of farmers prefer capsicum crop under protected structures followed by cucumber. 
The data indicates that capsicum crop was cultivated by 67.86 per cent of respondents in poly house while 51.79 per cent of the respondents were cultivating capsicum in net house and only 16.07 per cent of the respondents were cultivating capsicum in low tunnel technology for off season production (Table 2). Cucumber was grown in poly house by 58.82 per cent of the respondents while 29.41 per cent of the respondents were cultivating cucumber in net house and 33.33 per cent were growing cucumber in low tunnel technology (Table 2). In case of tomato, majority of respondents (94.74\%) were growing tomato in poly house while 63.16 per cent of respondents were cultivating in net house and only 15.79 per cent of the respondents were cultivating tomato crop in low tunnel technology (Table 2). It can be observed that majority of capsicum, cucumber and tomato growers were cultivating these crops under poly house followed by net house.

\section{Preparation of soil before sowing under protected cultivation}

The various practices for preparation of soil before sowing under protected structures were asked from respondents and data in Table 3 indicates that soil testing before sowing of crop was done by $62.50,84.21$ and 56.86 per cent of respondents in capsicum, tomato and cucumber crops respectively under protected structures. Soil testing provides the actual micronutrient status in soil. For the preparation of soil, deep ploughing was followed by 41.07, 26.32 and 52.94 per cent of respondents in capsicum, tomato and cucumber crops respectively while 59.93, 73.68 and 47.06 per cent of the respondents followed shallow ploughing to prepare the field in capsicum, tomato and cucumber crops respectively (Table 3 ). Soil solarisation was followed by $30.40,68.40$ and 23.50 per cent of the respondents in capsicum, tomato and cucumber crop respectively while 69.60,
31.60 and 76.50 per cent of respondents did not followed soil solarisation practices in capsicum, tomato and cucumber crops respectively before sowing (Table 3 ). About 86 per cent of the respondents used organic formulations in capsicum crop while 84.21 and 68.63 per cent of respondents used organic formulations in tomato and cucumber crop respectively. It was seen from the data in Table 3 that $14.29,15.79$ and 31.37 per cent of the respondents did not applied organic formulation in capsicum, tomato and cucumber crops respectively. Data in Table 3 concluded that majority of the respondents followed soil testing practices, shallow soil ploughing and applied organic formulation before sowing of capsicum, tomato and cucumber crop under protected structures. Majority of respondents did not follow soil solarisation practices for capsicum and cucumber while it was followed by maximum number of tomato growers under protected structure.

Organic formulations play a very significant role to enhance the growth and production of vegetable crops by providing appropriate amount of macro and micro nutrients (Gelsomino et al., 2010). Majority of respondents applied neem cake as organic formulation (85.42 per cent) in capsicum crop while 93.75 per cent and 77.40 per cent of respondents used it in tomato and cucumber crops respectively before sowing (Table 4). Tobacco powder was used only in capsicum crop by nearly four per cent of respondents. About eight per cent, 43.75 and 20 per cent of respondents used mustard cake in capsicum, tomato and cucumber crop respectively (Table 4). Jeev amrit was used only in capsicum and cucumber crop by nearly six and nine per cent of the respondents respectively. The data further revealed that $45.83,25$ and 85.71 per cent of the respondents used trichoderma and vermicompost as organic formulations in their crops respectively (Table 4). Neem cake, 
trichoderma and vermicompost were mostly used by respondents under protected structures in capsicum, tomato and cucumber crop.

Majority of the respondent i.e. 65.72, 50 and 79.32 per cent followed the soil testing practices before sowing to get actual micronutrient status of the soil for cultivation of capsicum, tomato and cucumber crops respectively (Table 5). The reason to reduce the fertilizer investment for soil testing was reported by $34.28,50$ and 20.68 per cent of the respondents in capsicum, tomato and cucumber crops respectively. The respondents were also asked about reasons for not following soil testing practices and data in Table 5 depicted that about ten per cent, 33.33 per cent and nearly nine per cent of respondents did not follow soil testing practices because they felt that there was no need to test the soil in capsicum, tomato and cucumber crop respectively while 47.62, 33.33 and 45.45 per cent considered it as a time consuming process.

More than 42, 33.33 and 45.45 per cent of respondents reported that soil testing laboratory was far away from field as main reason for not testing soil in capsicum, tomato and cucumber crop respectively.

Table.1 Distribution of respondents according to crops grown

\begin{tabular}{|l|c|c|}
\hline \multicolumn{1}{|c|}{ Crops } & Frequency* & Percentage \\
\hline Capsicum & 56 & 64.37 \\
\hline Cucumber & 51 & 58.62 \\
\hline Tomato & 19 & 21.84 \\
\hline Capsicum + tomato & 8 & 9.20 \\
\hline Capsicum +cucumber & 14 & 16.09 \\
\hline Tomato+ cucumber & 5 & 5.75 \\
\hline Tomato+ cucumber +capsicum & 6 & 6.90 \\
\hline
\end{tabular}

*Multiple Response

Table.2 Distribution of respondents according to crops grown under different protected structures

\begin{tabular}{|c|c|l|c|c|}
\hline S. No. & Crops & Structure & Frequency & Percentage \\
\hline 1. & \multirow{2}{*}{$\begin{array}{c}\text { Capsicum } \\
(\mathbf{n = 5 6} *\end{array}$} & Poly house & 38 & 67.86 \\
\cline { 3 - 5 } & & Net house & 29 & 51.79 \\
\cline { 3 - 5 } & \multirow{2}{*}{$\begin{array}{c}\text { Cucumber } \\
(\mathbf{n = 5 1} *\end{array}$} & Low tunnel & 9 & 16.07 \\
\cline { 3 - 5 } & & Poly house & 30 & 58.82 \\
\cline { 3 - 5 } & & Net house & 15 & 29.41 \\
\cline { 3 - 5 } & \multirow{3}{*}{3.} & Low tunnel & 17 & 33.33 \\
\hline \multirow{2}{*}{ Tomato $(\mathbf{n = 1 9}) *$} & Poly house & 18 & 94.74 \\
\cline { 3 - 5 } & & Net house & 12 & 63.16 \\
\cline { 3 - 5 } & & Low tunnel & 3 & 15.79 \\
\hline
\end{tabular}

*Multiple Response 
Table.3 Distribution of respondents according to soil preparation followed under protected cultivation of vegetables

\begin{tabular}{|c|c|c|c|c|c|}
\hline \multirow[t]{2}{*}{ S. No. } & \multirow[t]{2}{*}{ Cultural practices } & \multirow[t]{2}{*}{ Category/Range } & Capsicum n=56 & Tomato $n=19$ & Cucumber $n=51$ \\
\hline & & & Frequency (\%) & Frequency (\%) & Frequency $(\%)$ \\
\hline \multirow[t]{2}{*}{1.} & \multirow[t]{2}{*}{ Soil testing } & Yes & $35(62.50)$ & $16(84.21)$ & $29(56.86)$ \\
\hline & & No & $21(37.50)$ & $3(15.79)$ & $22(43.14)$ \\
\hline \multirow[t]{2}{*}{2.} & \multirow[t]{2}{*}{ Soil Preparation } & Deep ploughing & $23(41.07)$ & $5(26.32)$ & $27(52.94)$ \\
\hline & & Shallow ploughing & $33(59.93)$ & $14(73.68)$ & $24(47.06)$ \\
\hline \multirow[t]{2}{*}{3} & \multirow[t]{2}{*}{ Soil Solarisation } & Yes & $17(30.40)$ & $13(68.40)$ & $12(23.50)$ \\
\hline & & No & $39(69.60)$ & $6(31.60)$ & $39(76.50)$ \\
\hline \multirow[t]{2}{*}{4} & \multirow{2}{*}{$\begin{array}{l}\text { Organic } \\
\text { Formulations }\end{array}$} & Yes & $48(85.71)$ & $16(84.21)$ & $35(68.63)$ \\
\hline & & No & $8(14.29)$ & $3(15.79)$ & $16(31.37)$ \\
\hline
\end{tabular}

Table.4 Distribution of respondents according to type of organic formulations applied under protected cultivation of vegetables

\begin{tabular}{|c|l|c|c|c|}
\hline \multirow{2}{*}{ S. No. } & \multicolumn{1}{|c|}{ Organic formulations } & Capsicum n=48* & Tomato n=16* & Cucumber n=35* \\
\cline { 3 - 5 } & & Frequency (\%) & Frequency (\%) & Frequency (\%) \\
\hline 1 & Neem cake & $41(85.42)$ & $15(93.75)$ & $27(77.40)$ \\
\hline 2 & Tobacoo Powder & $2(4.17)$ & - & - \\
\hline 3 & Mustard Cake & $4(8.33)$ & $7(43.75)$ & $3(20.00)$ \\
\hline 4 & JeevAmrit & $3(6.25)$ & - & $3(8.57)$ \\
\hline 5 & Trichoderma and vermicompost & $22(45.83)$ & $4(25.00)$ & $30(85.71)$ \\
\hline
\end{tabular}


Table.5 Distribution of respondents according to reasons for soil testing and soil solarisation under protected cultivation of vegetables

\begin{tabular}{|c|c|c|c|c|c|c|}
\hline \multirow[t]{2}{*}{ S. No. } & \multirow{2}{*}{$\begin{array}{l}\text { Cultural } \\
\text { practices }\end{array}$} & \multirow[t]{2}{*}{ Category } & \multirow[t]{2}{*}{ Reasons } & Capsicum & Tomato & Cucumber \\
\hline & & & & Frequency $(\%)$ & Frequency $(\%)$ & Frequency $(\%)$ \\
\hline \multirow[t]{5}{*}{1} & \multirow[t]{5}{*}{ Soil testing } & \multirow{2}{*}{$\begin{array}{l}\text { Yes } \\
(n=35 \text { for capsicum) } \\
(n=16 \text { for tomato }) \\
(n=29 \text { for cucumber })\end{array}$} & $\begin{array}{l}\text { To get micronutrient status of } \\
\text { soil }\end{array}$ & $23(65.72)$ & $8(50.00)$ & $23(79.32)$ \\
\hline & & & Reduce fertilizer investment & $12(34.28)$ & $8(50.00)$ & $6(20.68)$ \\
\hline & & \multirow{3}{*}{$\begin{array}{l}\text { No } \\
\text { ( } n=21 \text { for capsicum) } \\
(n=3 \text { for tomato) } \\
(n=22 \text { for cucumber })\end{array}$} & No need & $2(9.52)$ & $1(33.33)$ & $2(9.10)$ \\
\hline & & & $\begin{array}{l}\text { Time consuming (report requires } \\
10 \text { days minimum) }\end{array}$ & $10(47.62)$ & $1(33.33)$ & $10(45.45)$ \\
\hline & & & $\begin{array}{l}\text { Soil testing laboratory is far } \\
\text { away from village }\end{array}$ & $9(42.86)$ & $1(33.33)$ & $10(45.45)$ \\
\hline \multirow[t]{4}{*}{2} & \multirow{4}{*}{$\begin{array}{c}\text { Soil } \\
\text { Solarisation }\end{array}$} & \multirow{2}{*}{$\begin{array}{l}\text { Yes } \\
(n=17 \text { for capsicum) } \\
(n=13 \text { for tomato }) \\
(n=12 \text { for cucumber })\end{array}$} & To reduce the soil born infection & $12(70.60)$ & $12(92.30)$ & $7(58.30)$ \\
\hline & & & To control nematodes & $5(29.40)$ & $1(7.70)$ & $5(41.70)$ \\
\hline & & \multirow{2}{*}{$\begin{array}{l}\text { No } \\
(n=39 \text { for capsicum) } \\
(n=6 \text { for tomato) } \\
(n=39 \text { for cucumber })\end{array}$} & Time consuming & $27(69.23)$ & $2(33.33)$ & $16(41.03)$ \\
\hline & & & Requirement of more labour & $12(30.77)$ & $4(66.67)$ & $23(58.97)$ \\
\hline
\end{tabular}


Table.6 Distribution of respondents according to sowing practices followed in capsicum under protected cultivation

\begin{tabular}{|c|c|c|c|}
\hline Crop & $\begin{array}{l}\text { Sowing } \\
\text { Practices }\end{array}$ & Practices followed & $\begin{array}{c}\text { Frequency } \\
(\%)\end{array}$ \\
\hline \multirow{18}{*}{ Capsicum } & \multirow{2}{*}{$\begin{array}{l}\text { Nursery } \\
\text { raising }\end{array}$} & Yes & $56(100.00)$ \\
\hline & & No & - \\
\hline & \multirow{2}{*}{$\begin{array}{l}\text { Method of } \\
\text { nursery } \\
\text { raising }\end{array}$} & Field & $36(64.29)$ \\
\hline & & Plug tray & $20(35.71)$ \\
\hline & \multirow[t]{3}{*}{ Seed rate } & Less than recommended (50g to $170 \mathrm{~g} / \mathrm{acre})$ & $21(37.50)$ \\
\hline & & Recommended (200 g/acre) & $20(35.71)$ \\
\hline & & More than recommended ( $225 \mathrm{~g}$ to $400 \mathrm{~g} / \mathrm{acre})$ & $15(26.79)$ \\
\hline & \multirow[t]{2}{*}{$\begin{array}{l}\text { Seed } \\
\text { Treatment }\end{array}$} & $\begin{array}{l}\text { Treatment done } \\
\text { Recommended: Captan or Thiram @ } 3 \text { g per Kg or } \\
\text { Bavisitin@ } 2 \mathrm{~g} / \mathrm{Kg}\end{array}$ & $5(8.93)$ \\
\hline & & Purchased pre treated seed & $51(91.07)$ \\
\hline & \multirow[t]{3}{*}{ Sowing time } & $\begin{array}{l}\text { Before recommended time } \\
\text { (Poly house and Net house: March or July, Low } \\
\text { tunnel: August) }\end{array}$ & $8(14.28)$ \\
\hline & & $\begin{array}{l}\text { Recommended } \\
\text { (Poly house and Net house:1st week of August, } \\
\text { Low tunnel: October) }\end{array}$ & $17(30.36)$ \\
\hline & & $\begin{array}{l}\text { After recommended time } \\
\text { (Poly house and Net house: October-November, } \\
\text { Low tunnel: November- January) }\end{array}$ & $31(55.36)$ \\
\hline & \multirow[t]{3}{*}{ Spacing } & $\begin{array}{l}\text { Less than recommended } \\
\text { (Plant to Plant } 30 \mathrm{~cm} \text { and Row to Row } 40 \mathrm{~cm} \text { in } \\
\text { triangle shape and Bed to Bed } 80 \mathrm{~cm} \text { ) }\end{array}$ & $15(26.79)$ \\
\hline & & $\begin{array}{l}\text { Recommended } \\
\text { (Plant to Plant } 45 \mathrm{~cm} \text { and Row to Row } 45 \mathrm{~cm} \text { in } \\
\text { triangle shape and Bed to Bed } 105 \mathrm{~cm} \text { ) }\end{array}$ & $22(39.28)$ \\
\hline & & $\begin{array}{l}\text { More than recommended } \\
\text { (Plant to Plant } 50 \mathrm{~cm} \text { and Row to Row } 50 \mathrm{~cm} \text { in } \\
\text { triangle shape and Bed to Bed } 1.6 \mathrm{~m} \text { ) }\end{array}$ & $19(33.93)$ \\
\hline & \multirow[t]{3}{*}{$\begin{array}{l}\text { Transplanting } \\
\text { time }\end{array}$} & $\begin{array}{l}\text { Before recommended time } \\
\text { (Poly house and Net house: June to August, Low } \\
\text { tunnel: October) }\end{array}$ & $9(16.07)$ \\
\hline & & $\begin{array}{l}\text { Recommended time } \\
\text { (Poly house and Net house: } 2^{\text {nd }} \text { or } 3^{\text {rd }} \text { week of } \\
\text { September: Low tunnel: End November) }\end{array}$ & $17(30.36)$ \\
\hline & & $\begin{array}{l}\text { After Recommended time (Poly house and Net } \\
\text { house: End October-first fortnight of November, } \\
\text { Low tunnel: January- February) }\end{array}$ & $30(53.57)$ \\
\hline
\end{tabular}


Table.7 Distribution of respondents according to sowing practices followed in tomato under protected cultivation

$\mathrm{n}=19$

\begin{tabular}{|c|c|c|c|}
\hline Crop & $\begin{array}{c}\text { Sowing } \\
\text { Practices }\end{array}$ & Practices followed & $\begin{array}{l}\text { Frequency } \\
\quad(\%)\end{array}$ \\
\hline \multirow{20}{*}{ Tomato } & \multirow{2}{*}{$\begin{array}{l}\text { Nursery } \\
\text { raising }\end{array}$} & Yes & $13(68.43)$ \\
\hline & & No & $6(31.57)$ \\
\hline & \multirow{2}{*}{$\begin{array}{l}\text { Method of } \\
\text { nursery } \\
\text { raising }(n=13)\end{array}$} & Field & $5(38.46)$ \\
\hline & & Plug tray & $8(61.54)$ \\
\hline & \multirow{3}{*}{$\begin{array}{l}\text { Seed rate } \\
(\mathrm{n}=13)\end{array}$} & Less than recommended ( $75 \mathrm{~g} / \mathrm{acre})$ & $8(61.54)$ \\
\hline & & Recommended (100g/acre for tomato) & - \\
\hline & & More than recommended (200g/acre) & $5(38.46)$ \\
\hline & \multirow{2}{*}{$\begin{array}{l}\text { Seedling rate } \\
(\mathrm{n}=6)\end{array}$} & Less than recommended ( 8000 seedlings/acre) & $3(50.00)$ \\
\hline & & Recommended (10000seedlings/acre) & $3(50.00)$ \\
\hline & \multirow[t]{2}{*}{$\begin{array}{l}\text { Seed } \\
\text { Treatment } \\
(n=13)\end{array}$} & $\begin{array}{l}\text { Treatment done } \\
\text { Recommended (Captain or Thiram @ } 3 \text { g per Kg or } \\
\text { Bavisitin@ } 2 \mathrm{~g} / \mathrm{Kg} \text { ) }\end{array}$ & $4(30.77)$ \\
\hline & & Purchased pre treated seed & $9(69.23)$ \\
\hline & \multirow[t]{3}{*}{ Sowing time } & $\begin{array}{l}\text { Before recommended time (Poly house and Net } \\
\text { house: August, Low tunnel: August to September) }\end{array}$ & $11(57.90)$ \\
\hline & & $\begin{array}{l}\text { Recommended time (Poly house and Net house: Mid } \\
\text { September-mid October, Low tunnel: October) }\end{array}$ & $4(21.05)$ \\
\hline & & $\begin{array}{l}\text { After recommended time (Poly house and Net house: } \\
1^{\text {st }} \text { week of November, Low tunnel November) }\end{array}$ & $4(21.05)$ \\
\hline & \multirow[t]{3}{*}{ Spacing } & $\begin{array}{l}\text { Less than recommended (Plant to Plant } 30 \mathrm{~cm} \text { and } \\
\text { Row to Row } 40 \mathrm{~cm} \text { and Bed to Bed } 80 \mathrm{~cm} \text { ) }\end{array}$ & $5(26.32)$ \\
\hline & & $\begin{array}{l}\text { Recommended (Plant to Plant } 30 \mathrm{~cm} \text { and Row to } \\
\text { Row } 60 \mathrm{~cm} \text { and Bed to Bed } 90 \mathrm{~cm} \text { ) }\end{array}$ & $3(15.79)$ \\
\hline & & $\begin{array}{l}\text { More than recommended (Plant to Plant } 45 \mathrm{~cm} \text { and } \\
\text { Row to Row } 45 \mathrm{~cm} \text { and Bed to Bed } 1.6 \mathrm{~m} \text { ) }\end{array}$ & $11(57.89)$ \\
\hline & \multirow[t]{3}{*}{$\begin{array}{l}\text { Transplanting } \\
\text { time }\end{array}$} & $\begin{array}{l}\text { Before recommended time (Poly house and Net } \\
\text { house: August to end September, Low tunnel: } \\
\text { October) }\end{array}$ & $4(21.05)$ \\
\hline & & $\begin{array}{l}\text { Recommended time (Poly house and Net house: Mid } \\
\text { October-mid November (40-45 DAS), Low tunnel: } \\
\text { November }\end{array}$ & $10(52.64)$ \\
\hline & & $\begin{array}{l}\text { After recommended time (Poly house and Net house: } \\
1^{\text {st }} \text { week of December, Low tunnel: End December- } \\
\text { January) }\end{array}$ & $5(26.31)$ \\
\hline
\end{tabular}


Table.8 Distribution of respondents according to sowing practices followed in cucumber under protected cultivation of vegetables

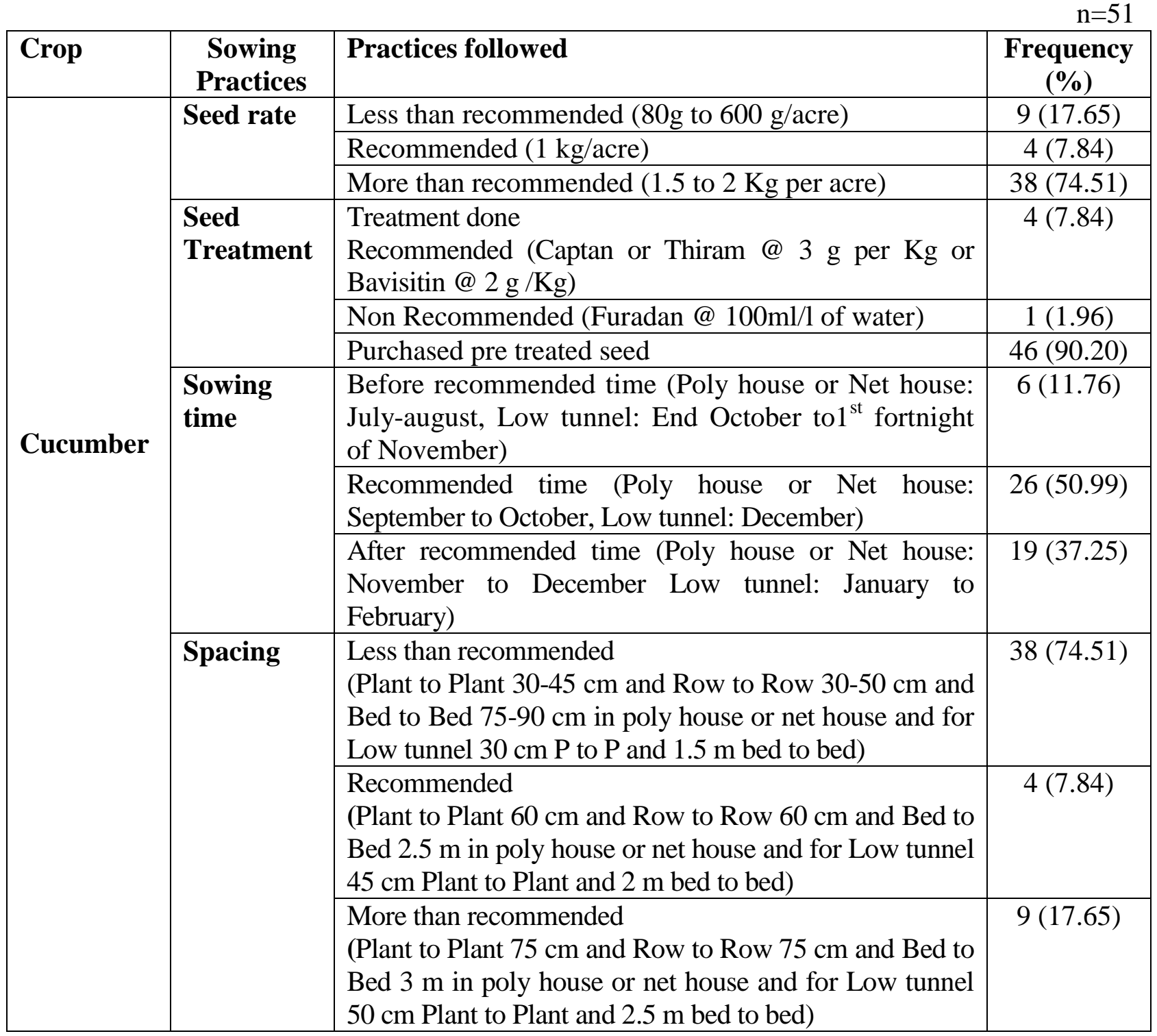

Soil solarisation was done by 70.6 per cent of respondents in capsicum crop, 92.3 per cent in tomato crop and 58.3 per cent in cucumber crop (Table 5). To control the nematodes, soil solarisation was followed by 29.4 per cent, 7.70 per cent and 41.7 per cent of respondents in capsicum, tomato and cucumber crops respectively. While 69.23, 33.33 and 41.03 per cent of the respondents considered soil solarisation as a time consuming process and requirement of more labour was reported as a reason for not following soil solarisation practices by $30.77,66.67$ and 58.97 per cent of the respondents in capsicum, tomato and cucumber crops respectively (Table 5).

It was observed that to get the actual micronutrient status of soil was the main reason of soil testing for majority of vegetable growers under protected structures and time consuming process was the main reason for not to follow the soil testing practices in capsicum, tomato and cucumber crop in protected structures. While, to reduce the soil 
born infections was the main reason of soil solarisation under protected structures.

\section{Sowing practices of different vegetable crops under protected structures}

\section{Capsicum}

Majority of the respondent (55.36 per cent) had sown the capsicum crop after the recommended time (Table 6) while about 30 per cent of respondents sown capsicum at recommended time and only 14.28 per cent of them sown the capsicum crop before the recommended time under protected structures. Similar results were reported by Sharma, (2002) that majority of respondents did not sow okra at recommended time. In case of seed rate application, 37.50 per cent of respondents used less than recommended seed rate followed by 35.71 per cent of respondents used recommended seed rate and about 27 per cent of them used more than recommended seed rate of capsicum crop for sowing under protected structures (Table 6). Similar results were reported by Khangura and Arneja, (2003) in pea that majority of pea growers did not apply recommended seed rate.

All the respondents grew their own nursery for capsicum crop out of which 64.29 per cent grew nursery directly in field and 35.71 per cent used plug trays to grow the nursery (Table 6). It was further observed that 39.28 per cent of respondents sown the capsicum crop at recommended spacing followed by 33.93 per cent sown the crop at more than recommended spacing while 26.79 of them sown the crop at less than recommended spacing under protected structures (Table 6) Results are in line with Schreinemachers et al., (2016) in tomato. Majority of the respondents $(91.07 \%)$ purchased pretreated seed of capsicum for cultivation under protected structures while about nine per cent of them followed seed treatment with recommended chemicals under protected structure cultivation (Table 6). Transplanting of the seedling delayed by majority of the respondents $(53.57 \%)$ while 30.36 per cent of them transplanted the capsicum nursery at recommended time whereas small percentage of the respondents $(16.07 \%)$ reported early transplanting before the recommended time in capsicum crop under protected structures (Table 6).

\section{Tomato}

Majority of the respondents i.e. 57.90 per cent had sown the tomato crop before the recommended time while, 21.05 per cent of respondents sown the crop at recommended time (Table 7). Whereas 21.05 per cent of respondents sown the tomato crop after the recommended time under protected structures. Similar results were reported by Sharma, (2002) in okra cultivation under open field cultivation. Whereas 61.54 per cent of respondents used less than recommended seed rate followed by 38.46 per cent sown with more than recommended seed rate of tomato crop. None of the respondent had sown the tomato crop with recommended seed rate under protected structures (Table 7). Similar results were reported by Khangura and Arneja (2003) in pea cultivation.

About 69 per cent of the respondents grew their own nursery for tomato crop out of which 38.46 per cent grown nursery directly in field and 61.54 per cent used plug trays to grow the nursery of tomato (Table 7). It was noticed that 31.57 per cent of the respondents did not grown the nursery and purchased the seedlings, out of which half of the respondents used recommended number of seedling while remaining half used less than recommended number of seedlings. About 16 per cent of respondents sown the crop at recommended spacing while, 57.89 per cent 
of respondents sown tomato at more than recommended spacing while 26.32 per cent of them were sown the crop at less than recommended spacing under protected structures. Similar results were reported by Schreinemachers et al., (2016) in tomato crop under protected structures. Majority of the respondents $(69.23 \%)$ sown pretreated seeds of tomato crop while 30.77 per cent of them followed seed treatment with recommended chemicals under protected structures (Table 7). Transplanting of the tomato seedling delayed by 26.31 per cent of the respondents and majority of respondents (52.64\%) transplanted the tomato under protected structures at recommended time whereas 21.05 per cent of the respondents reported early transplanting before the recommended time in tomato (Table 7).

\section{Cucumber}

Majority of the respondent i.e. 50.99 per cent had sown the cucumber crop at the recommended time while, 37.25 per cent of respondents sown cucumber crop after the recommended time and only 11.76 per cent of the respondent sown the cucumber crop before the recommended time under protected structures (Table 8). Similar results were reported by Ramesh and Singh, (2007) in organic farming of vegetables. About 75 per cent of respondents used more than recommended seed rate while, 17.65 per cent of respondents used less than recommended rate of cucumber seed and about eight per cent of the respondents sown the crop with recommended seed rate under protected structures (Table 8). Similar results were reported by Sharma, (2002) in okra.

About eight per cent of the respondents had sown the crop at recommended spacing and 17.65 per cent of respondents sown the crop at more than recommended spacing while majority $(74.51 \%)$ of them sown the crop at less than recommended spacing under protected structures (Table 8). Similar results were reported by Khangura and Arneja, (2003) in pea cultivation. Majority of the respondents $(90.20 \%)$ sown pretreated seed of cucumber while about eight per cent of them followed seed treatment with recommended chemicals (Table 8).

It was concluded that capsicum crop followed by cucumber was mostly adopted by farmers in poly house and net house. Soil solarisation practices were not followed by majority of the respondents in capsicum and cucumber crop under protected structures. Majority of respondents did not adopt recommended sowing practices for capsicum, tomato and cucumber under different protected conditions. Therefore regular awareness camps and training courses should be organised to train the farmers for successful cultivation of vegetable crops under protected structures and adoption of these technologies at large scale.

\section{Acknowledgement}

All the authors would like to thank the authorities of Punjab Agricultural University, Ludhiana and Department of Horticulture, Punjab, India, for providing facilities to complete the research work successfully.

\section{References}

Anonymous, 2016. Statistical abstract of Punjab. Government of Punjab, Chandigarh. Pp: 147-216.

Chandra, P., Sirohi, P.S., Behera, T.K., and Singh, A.K. 2000. Cultivating vegetables in poly house. Indian Journal of Horticulture 45: 17-25.

Gelsomino, A., Abenavoli, M.R., Princi, G., Attina, E., Cacco, G., and Sorgona, A. 2010. Compost from fresh orange waste: a suitable substrate for nursery 
and field crops. Compost Science and utilization 18: 255-267.

George, S., and Singh, A. 2006. Vegetables for health and nutrition security. Yojana 40: 36-40.

Khangura, R.S., and Arneja, C.S. 2003. Adoption of selected pea cultivation practices as followed by pea growers. Agricultural Research Journal 40:26068.

Kumar, P. 2008. Status of protected cultivation of vegetable by the farmers of Punjab. M.Sc. Thesis, Punjab Agricultural University, Ludhiana, India.

Ramesh, P., and Singh, A.B. 2007. Feasibility of organic farming- A farmers' survey in Madya Pardesh. Kurukshetra 55: 2530.

Satyasai, K.J., and Viswanathan, K.U. 1996.
Diversification of Indian agriculture and food security. Indian Journal of Agricultural Economics 51: 674-79.

Schreinemachers, P., Wu, M., Uddin, N., Ahmad, S., and Hanson, P. 2016. Farmer training in off season vegetables: Effects on income and pesticide use in Bangladesh. Food Policy 61:132-40.

Sharma, S. 2002. Adoption of cultural practices of okra (Abelmoschus esculentus) crop by the farmers of Pakhowal block of Ludhiana district of Punjab. M.Sc. Thesis, Punjab Agricultural University, Ludhiana, India.

Weinberger, K., and Lumpkin, T.A. 2007. Diversification through horticulture and poverty reduction: a research agenda. World Development 35:1464-1480.

\section{How to cite this article:}

Kamalpreet Kaur, Prabhjot Kaur and Kulbir Singh. 2017. Adoption Status of Various Sowing Practices of Protected Cultivation of Vegetables in Punjab, India. Int.J.Curr.Microbiol.App.Sci. 6(12): 801-812. doi: https://doi.org/10.20546/ijcmas.2017.612.085 